\title{
A means end approach to domestic lead tourism marketing in emerging tourism destinations
}

\author{
Estone Musakabantu Muyobo \\ Evangelia Fragouli \\ University of Dundee, UK
}

\section{Keywords}

Domestic tourism; Laddering; Market segmentation; Means End Chain theory; Positioning; Targeting

\begin{abstract}
This research paper suggests the Means-End Chain theory, has relevant and potential application in domestic tourism research and, as such, should receive wider debate in emerging tourism destinations. It is argued that the theory is particularly useful for understanding personal values as the basis of tourist behavior. This paper argues a personal values approach is a more potent way to understanding domestic tourist participation in contrast to previous survey research findings. A dominate narrative in most developing nations is to target domestic tourist with amenities envisioned for global tourists as a result of failure to generate international tourist demand. The review of literature method was used in this research paper as methodological approach. The study shows the effectiveness of Means End Chain analysis in understanding travel markets and demonstrated the use of motivation chains as a basis for segmenting, positioning, and targeting domestic tourist; The study deduces that means end chain analysis has advantages over quantitative research methods in cross-cultural research given the ability of the approach to reveal unique insights.
\end{abstract}

Corresponding author: Estone Musakabantu Muyobo

Email addresses for the corresponding author:memuyobo@dundee.ac.uk

The first submission received: $8^{\text {th }}$ December 2020

Revised submission received: $13^{\text {th }}$ April 2021

Accepted: $20^{\text {th }}$ April 2021

\section{Introduction}

Over the last decade renewed interest in domestic tourism participation as a mechanism to foster robust tourism in developing countries can be seen from the numerous books, articles, and dissertations on the subject, contrary to the dominant narrative of the tourism industry propelled by Western tourists. Early experts in tourism management and marketing have linked domestic participation to a number of factors, such as economic growth, enhanced tourism amenities and resource-based approaches. In addition, the direct application of marketing and management principles to domestic tourism participation is evident. For instance, Cohen et al, (2014) argue individual studies replicating one or a few consumer behaviour concepts borrowed from marketing and general management fields and applying them to tourism and many studies investigate the same effect (e.g., satisfaction loyalty), but the results cannot be compared due to differences in the research contexts based on tourist types or destinations, thereby hindering generalisation. As a result, the consumer attitude survey research has dominated tourism marketing with product attributes emerging as a focal point or putting it in other words the reason why superior performance of an attribute matters to the consumer of the tourism product.

\section{Conceptual Framework}

A conceptual framework is evolved that shows the relationship between possible exploitation of tourism potentials of emerging tourism markets, opportunities for domestic tourism to generate greater participation would depend upon embracing a marketing-oriented approach based on a values concept or Means End Chain theory (MEC). The conceptual framework thus shows the linkage between promotion of domestic tourism by the identification of domestic tourist market segmentation, positioning and targeting using the means end chain approach as an alternative to the profiling segmentation and product attribute approaches. 


\section{Literature review}

The means end approach assumes that consumers decide which products and services to buy based on the anticipated consequences (expected outcomes, need satisfied, goal or value achievement associated with each considered alternative. Means end chain theory additionally claims product attributes are less important in consumer decision making in comparison to anticipated consequences and personal values. (Olson and Reynolds, 2001). The Means End Chain can be used most effectively in understanding the two main issues in consumer decision making: i) what choice criteria consumers use to evaluate the choice alternatives and choose among them; and ii) why consumers find these particular choice criteria to be personally relevant (i. e. salient or important) (Olson and Reynolds 2001). Consumer involvement grows when marketers bring out personally relevant psychological and sociological reasons for consuming their products, and consequently, involvement can be manipulated by marketing programmes (Peter and Olson, 2005). Traditional attitude research focuses on determining the relative importance of attributes and measuring perceptions about how well products perform with respect to important attributes, whilst means-end research focuses on determining the key choice criteria underlying a purchase decision, identifying how the choice criteria relate to product attributes, and understanding the reasons why the product attributes and related choice criteria are important or personally relevant to consumers (Whitlark et al., 2001; Cohen and Warlop, 2011).

\section{Domestic tourism}

The growing attention for quality from the consumer perspectives is an important development in the tourism industry (Jeng and Yeh, 2016). The World Tourism Organisation (WTO) also endorses this advantage and includes this as a major thrust in its "Tourism Vision 2020" which is a strategic thinking on priorities needed for countries seeking tourism development.

Quinn (2010) defines domestic tourism as the travel by residents of a country within the country, which can be same day or overnight within or outside the same state and territory but excluding travelling for work or school. The term residents in tourism literature refers to host community (Yang, 2012); local communities (Dadvar-Khani, 2012); rural communities (Eusébio and Carneiro, 2012); hosting communities (Lima and d'Hauteserre, 2011); community (Lepp, 2008).

In this research paper the broad definition of domestic tourism proposed by Hall and Lew (2009) is adopted. According to Hall and Lew (2009) the domestic tourism is the tourism of residents within the economic territory of the country of reference (Hall and Lew, 2009). Calls for many developing countries to develop and market their tourism potential is evident with significant gains recorded and emphasis placed on international and global arrivals (Mbaiwa et al., 2007). Despite consistent apathy within the developing world in developing domestic tourism, the sector has demonstrated its importance especially when used as a complementary segment, to the volatile international market. Domestic tourism has been noted to foster national pride among citizens, bridge the seasonality gap, increase employment and investment opportunities as well as increase benefits to SMEs (Bui and Jolliffe, 2011). However, the adoption of domestic tourism for sustainable tourism development is lagging in developing countries (Rogerson and Lisa, 2005; Scheyvens, 2007). Sindiga (1996) argues the heavily reliant on international clients by most developing countries is unsustainable. Ritchie and Crouch, (1993) suggest the continued neglect of domestic tourism by developing countries will continue to render their tourism industries unstable.

\section{The pros and cons of domestic tourism}

According to World Travel and Tourism Council (WTTC) report, domestic tourism accounts for $73 \%$ of total Travel and Tourism spending globally in 2018; Domestic tourism seems to be a key driver of the tourism sector. Countries rely on domestic tourism as a tool to reduce poverty, improve infrastructure, generate employment and most importantly to drive economic growth.

The activities of domestic tourists create economic importance as the money spent on domestic tourism feeds back into that particular country's economy, providing itself with a more viable and prosperous economy. Domestic tourism is considered as a development factor, domestic tourism brings about an intermingling of people from diverse social and cultural backgrounds and also a considerable redistribution of spending power (Archer, 1978). Finally considering that the domestic tourism does not 
regard exchange of tourists with cultural differences from hosts, so its impact is not obviously harmful as of international tourism and its impact on international cultures. However, besides the positive aspects there are also negative ones such a) economic (e.g landprice inflation, seasonal variations, dependence on a single industry) b) environmental and physical (overcrowding, congestion, noise, water, and air pollution in some areas) and c) social (e.g increases in crime, changes in mode of living, feelings of inferiority (Pizam, 1977 as stated in Archer, 1978) which of course can take place of any kind of tourists' mobility.

\section{Domestic tourism an African perspective}

The African countries are presented with numerous opportunities and challenges in marketing their tourism industries the vast tourism potentials are to a great extent limited to how Africa has been perceived and branded over many decades. The problem here is Africa's distorted destination image may pose significant implication in the realisation of international and global tourists as African countries are generally confronted with a negative brand identity which may pose challenges in attracting international arrivals (Lepp et al., 2011), a risky continent (Lepp, 2008; Carter, 1998) and a wild jungle (Brown, 2000; Carter, 1998). The image of a destination is an important factor taken into account by tourists when choosing a place to visit (Gallarza, Saura, and Garcia, 2002; Pike, 2005); due to its importance in enhancing tourist satisfaction and affecting the intention of tourists to repeat their visit (Pike, 2005; Prayag, 2008; Tasci and Gartner, 2007). In a recent study on domestic tourism in Southern Africa, Morupisi and Mokgalo (2017) reported an increasing outbound movement by local residents, for leisure purposes of which they suggest, illustrated a higher propensity to travel which is a precursor to tourism engagement. However, domestic tourism consumption failed to match the good outbound leisure travel behaviour. Kwenye (2015) shares similar views, pointing out, a common belief that Zambian citizens would prefer to vacation in other countries rather than visiting their own natural tourist settings. Such low domestic tourism observations however are not only unique to Zambia. Similar observations have been made in the developing world though with some noted improvements in South Africa - especially among the black African population (Butler and Richardson, 2013).

The literature dedicated to domestic tourism is relatively limited as most of the tourism literature focuses on international tourism. Notwithstanding its growth and potential to contribute to economic development, academic journals receive relatively few submissions based on research on domestic tourism in developing countries (Morupisi and Mokgalo, 2017). "Scholars investigating local residents' attitudes toward tourism have often used different types of measurement procedures based on positivistic paradigms" (Nunkoo and Ramkissoon, 2009.p.1). while very few researchers have based their studies on purely qualitative approaches. The neglect of domestic tourism by the wider literature has been identified by Cortes-Jimenez (2008), who describes tourism research as usually restricted to international tourism: "Most studies only analyse international tourism either because of unavailability of data or because of undervaluing domestic tourism" (p. 127). This bias against domestic tourism seems to be closely associated with the preoccupation of many governments to move tourism upscale and to maximize foreign exchange earnings (Cortes-Jimenez, 2008).

In conclusion to the above the following key point is deduced. The tourism product of developing nations is developed purely on attributes that appeal to international tourists whereby disregarding personal values and consequences of domestic tourists.

\section{Methodology}

The review of literature method was used in this research paper given that causal inference was possible using documentary evidence in attaining the key objective of the study; a values approach to understanding domestic tourism based on means end chain approach been a more potent way in understanding domestic tourist decision making in emerging tourism markets. Hence, a more practical method to achieve the study objective was to critically evaluate peer reviewed studies based on web searches, journals, and textbooks. However, as this paper is a part of a research work in process, to note that an empirical survey has been designed to take place where interviews have been scheduled through the distribution of a questionnaire to a purposeful selected research sample . 


\section{Findings/Results}

Some empirical studies have been reported using Means End Chain theory for market segmentation, positioning and target marketing within different emerging tourism destination contexts.

Pezeshk et al. (2019) using Means End Theory identified revealed 12 attributes, 11 consequences, and five values that domestic Iranian senior tourists wished to achieve. The study constructed a hierarchical value map (HVM) which specified how Iranian senior tourists linked various attributes of domestic tourism destinations to definite consequences, and how such consequences helped them to satisfy their individual values. The study used the laddering technique and in-depth interviews with 30 Iranian senior citizens. A hierarchical value map of Iranian senior tourists was constructed, which identified seven key means end chains (MECs). They recommended key basis for the segmentation of the domestic senior tourism market and the formulation of destination positioning strategies within Iran; $\mathrm{Li}$ and Cai (2012) identify six key Means End Chains examines the travel motivation of Chinese outbound tourists at the levels of attribute, consequence and values based on Means End Chain (MEC) theory and laddering method. Two major travel motivation chains were identified (1) respondents visit destinations that are 'famous' or have a 'good environment' because they value 'the beauty of nature' and 'pleasure' and (2) respondents want to visit 'different' destinations, because they value experiences and knowledge.

The study showed the effectiveness means end chain analysis in understanding travel market and demonstrate the use of motivation chains as the basis for segmenting the Chinese market; Watkins and Gnoth (2011) concluded that means end chain analysis has advantages over quantitative research methods in cross-cultural research. Their study revealed unique insights into Japanese travel experiences. They further argue that meaningful values research must consider not only those values that are commonly understood across cultures but also those that are particular to the culture in question, in order to understand what drives perception and satisfaction relevant for destination management and marketing. The findings of the study recommended on how to address a number of practical issues facing tourism practitioners, such as segmenting and positioning the domestic Japanese market; Nunkoo and Ramkissoon (2009) Found that the prevalence of socially oriented values (being with friends and family), whereas traditionally a museum visit has been linked to more individualistic values, such as education and knowledge.

This study recommended a key basis to reposition the Otago Museum in New Zealand. They deployed an exploratory study based on Means End Chain theory; In a study that examines the complexity and hierarchical nature of tourists' experiences at indigenous sites in Taiwan by Wua et al, (2019). Figure 1 below deconstructs experience patterns using a Means End Chain approach.

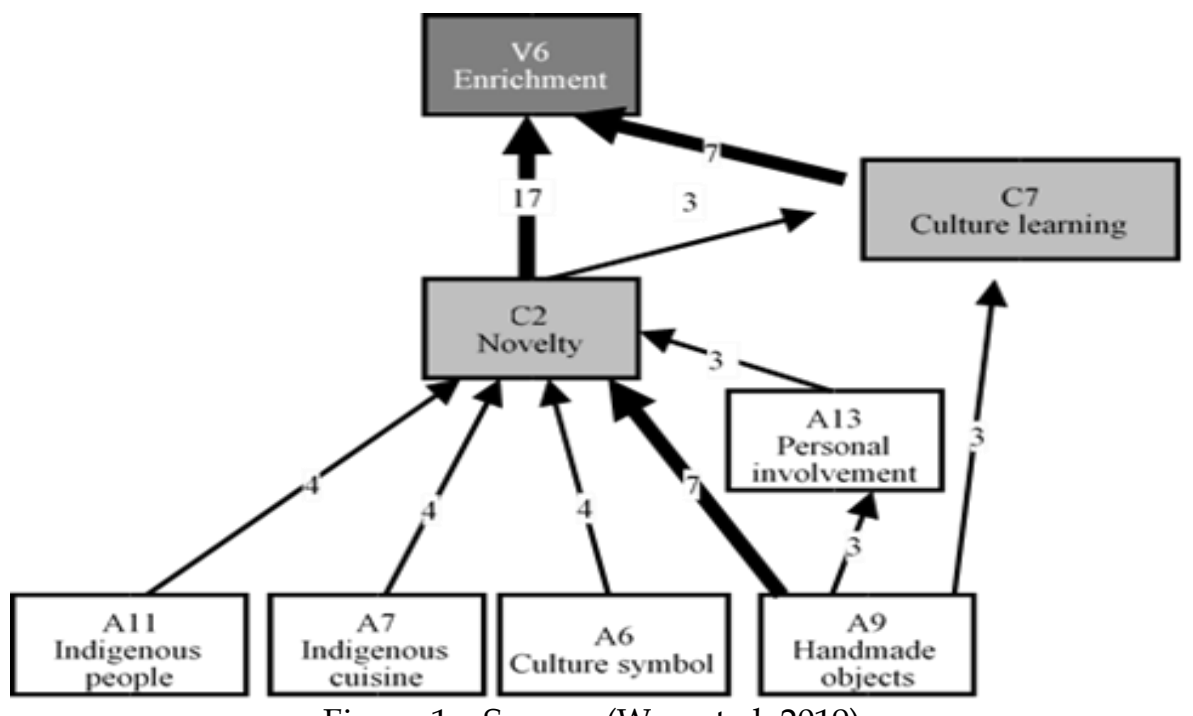

Figure 1 - Source: (Wua et al, 2019).

Their study found two value-led gains i) happiness and ii) enrichment. An experience spectrum was proposed from self-oriented, through self and others, to others-oriented, reflecting different 
orientations of pursuits that are expressed through experiencing indigenous tourism in various ways. Based on fifty-eight in-depth interviews hierarchical value maps were constructed. Three sets of indigenous tourism experiences were identified i) enjoying nature and a simple lifestyle ii) participating in indigenous activities, and iii) experiencing ethnic culture (see figure 2 below)

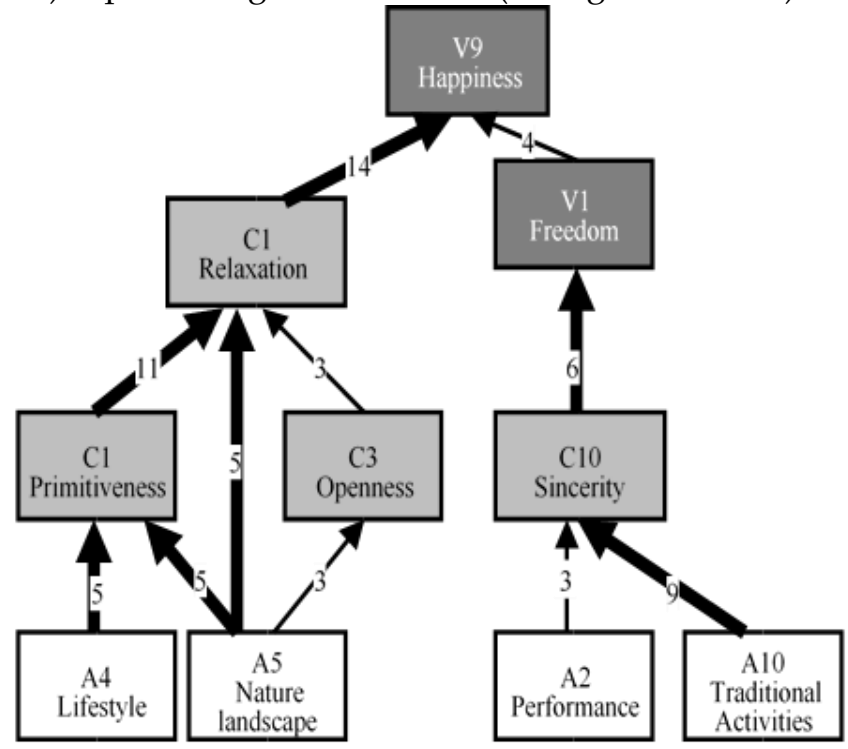

Figure 2 - Source: (Wua et al, 2019).

In a comparative study of Australian international tourists and Japanese domestic tourists Progano, Kumi and Cheer (2020) using Means End Chain theory at the Nakahechi trail of Kumano Kodo, an ancient pilgrimage site located in Tanabe city (Japan) developed for international tourism. Australian tourists were selected because they were the most numerous international visitors to the site. In order to bridge the research gap, their study objective was to examine visitor diversification in pilgrimage tourism through a study of similarities and differences of values among domestic and international visitors. Results showed a variety of similarities and differences between the sampled nationalities, demonstrating a growing diversification in sacred sites which incorporates a complex range of elements related to leisure, sports, intercultural exchange, nostalgia, escapism, and relaxation, beyond a continuum of contemporary spirituality and traditional religion. Progano, Kumi and Cheer (2020) concluded nationality is a fundamental factor for studying pilgrimage tourism in contemporary society. As pilgrimage sites continue to develop into international destinations, nationality is an important factor that requires further attention from academics. Results also have practical implications for local administrations aiming to develop their pilgrimage resources for domestic and international visitors.

\section{Conclusion and Discussions}

The empirical studies being reviewed have illustrated the Means end Chain approach could be employed as a standard consideration in market analysis and as a tool to achieve greater precision and effectiveness in market segmentation, positioning and target marketing. Careful assessment of values of domestic tourists and emerging value trends have allowed the identification of new product opportunities and the repositioning of existing products together with a more effective promotional strategy to create and reinforce a preference by appealing to centrally held values of the domestic tourists. Contrary, to an inability to provide accurate information for strategic marketing management is apparent the dominant positivism survey research approaches in tourism marketing, given a lack of homogeneity within members of a segment in terms of motivation, wants, needs, and behavioural patterns. Concomitantly, a general low level of correspondence between background variables and behaviour. Finally, the studies have shown that the Means End Chain approach when applied to domestic tourism has the ability to overcome the various challenges identified in the literature that impede maximum realization of the potential in domestic tourism at various levels, philosophical and methodological (Scott and Le, 2017), etic versus emic approaches (Toa, 2006; Maoz and Bekerman, 2010), policy and marketing related issues at 
destination management level (Mbaiwa et al., 2007; Michaud and Turner, 2006; Wu and Cai, 2006), others are more to do with socio-cultural and socio-economic aspects within destinations (Alipour et al., 2013; Cochrane, 2009).

\section{Limitations and directions for further research}

The critics to the Means End Chain Theory approach may represent the major limitation. For example, Bagozzi and Dabholkar (2000) point out two drawbacks to the means end chain approach. First, it presumes that people's reasons are organized from concrete, physical criteria to abstract, intangible criteria, where people are needed to conform to this a priori ordering in using the laddering procedure. Second, as a consequence of this assumption, the procedure works best for physical products and is less well adapted to the marketing of ideas, people, or services, which are contexts not readily described by physical properties. Although laddering has been applied to services, it appears to work best for services when physical attributes are clear they further argue perceptions of product attributes, psychosocial consequences, and values are taken as units of knowledge, and the ordered connections between these units are interpreted as inference-based judgments.

\section{Recommendations for further research}

Explore ways to make means end approach more appealing to Destination Marketing Organisations (DMO) and tourism organisations in emerging nations. This follows claims by Olson and Reynolds (2001) findings of Means End Chain studies are subject to consultative in-house studies by large organisations, hence, most studies are not made available and subject to copy right restrictions.

\section{Managerial and policy implications}

From a management perspective, domestic tourism must be supported financially by local governments since it adds value to local communities. Via new infrastructures, marketing policies of products and services being offered, financial support the value of domestic tourism and the importance of local societies will be promoted, strengthening local economies. Investment on training programs should take place developing specific skills, competencies and knowledge needed leading to improvement of services and product driven by actual needs of domestic tourists.

\section{References}

Archer, B. H (1978). Domestic Tourism as a Development Factor'. Annals of Tourism Research, Vol. V, No. 1, January/March 1978, pp. 126-141.

Bagozzi, R.P. and Dabholkar, P.A. (2000). Discursive Psychology: An Alternative Conceptual Foundation to Means-End Chain Theory. Psychology and Marketing John Wiley and Sons, Inc. 17(7):535-586.

Beckman, E. Whaley, J.E and Kim.Y (2009) Motivations and Experiences of Whitewater Rafting Tourists on the Ocoee River. International Journal of Tourism Research 19 (2).

Blackwell, R.D., Miniard, P.W., Engel, F.J. (2006), Consumer Behaviour. Mason: Thomson.

Brown, D.O. (2000), Political risk and other barriers to tourism promotion in Africa: perceptions of US-based travel intermediaries", Journal of Vacation Marketing: 6 (3), 197-210.

Brunso, K. Scholderer, J. and Grunert, K.G. (2004). Closing the Gap Between Values and Behaviour-A Means-End Theory of Lifestyle. Journal of business research 57(6): 665.6.

Carter, S. (1998), Tourists' and travellers' social constructions of Africa and Asia as risky locations. Tourism Management. 19 (4). 349-58.

Cortes-Jimenez, I. (2008). Which type of tourism matters to the regional economic growth? The cases of Spain and Italy International journal of tourism research. 10 (2). 127-139.

Cohen, S.A. Prayag, G. and Moital, M (2014). Consumer behaviour in tourism: Concepts, influences and opportunities: Current issues in Tourism Taylor and Francis. 10 (2) 872-909.

Cohen, J. B., and L. Warlop (2001). A Motivational Perspective on Means-End Chains. Understanding Consumer Decision Making - The Means-End Approach to Marketing and Advertising Strategy. T. J. Reynolds and J. C. Olson. London, Lawrence Erlbaurn Associates.

Gallarza, M. G. Saura, I. G. and Garciá, H. C. (2002). Destination image. Annals of Tourism Research, 29(1), 56-78.

Gnoth, J. (1997) Tourism motivation and expectation formation. Annals of Tourism Research 24(2): 283-304.

Eisenhardt, K.M and Graebner, M.E (2007). Theory Building from Cases: Opportunities and Challenges. Academy of management journal: 50 (1).

Eusébio, C.A and Carneiro, M.A (2012). Determinants of Tourist-Host Interactions: An Analysis of the University Student Market. Journal of Quality Assurance in Hospitality and Tourism. 13 (2). 123 - 151. 
Ghimire, K. B. (2013). The native tourist: Mass tourism within developing countries, Routledge.

Gertner, D. (2007), Place branding: dilemma or reconciliation between political ideology and economic pragmatism?", Place Branding and Public Diplomacy. 3 (1), 3-7.

Grunert, K.G and Grunert, S.C. (1995). Measuring subjective meaning structures by the laddering method: Theoretical considerations and methodological problems International Journal of Research in Marketing 12. 209-225 Hall, C. M. and Lew, A. A. (2009). Understanding and managing tourism impacts: An integrated approach, Routledge

Jeng, M. and Yeh, T. (2016). The effect of consumer values on the brand position of green restaurants by means-end chain and laddering interviews, Journal of Hospitality and Tourism Management 10 (1), 223-238.

Jiang, S. and Scott, N. and Ding, P. (2014). Using means-end chain theory to explore travel motivation. Journal of Vocational Marketing. 21, 87-100.

Kabote. F, Mamimine.P, and Muranda. Z, (2017) Domestic tourism for sustainable development in developing countries; University of Technology Zimbabwe.

Kotler, P. (2017) Principles of Marketing, 13th ed., Pearson Education, Upper Saddle River, NJ.

Kotler, P. T., Bowen, J. T., and Makens, J. (2014). Marketing for Hospitality and Tourism (6th Ed.). Essex: Pearson.

Krystallis, A. (2015). Motivation and cognitive structures of store versus manufacturer brand consumers. Journal of Consumer Behaviour. 14(4), 270-284.

Kwenye, J.M (2015). An investigation of domestic tourists' loyalty to a nature-based setting from a relational and transactional perspective at the Victoria Falls World Heritage site. The University of Montana

Li, M. and Cai, L.A. (2012). The Effects of Personal Values on Travel Motivation and Behavioral Intention, Journal of Travel Research. 51(4), 473-487

Lepp, A., Gibson, H. and Lane, C. (2011), Image and perceived risk: a study of Uganda and its official website, Journal of Tourism Management. 32 (3) 675-84.

Madrigal, R. and Kahle, L. R. (1994). Predicting Vacation Activity Preferences on the Basis of Value-System Segmentation. Journal of Travel Research, 32(3), 22-28

Maoz, D. and Bekerman, Z. (2010). SEARCHING FOR JEWISH ANSWERS IN INDIAN RESORTS: The Postmodern

Traveler. Annals of Tourism Research. 37 (2) 423 - 439

Morupisi, P. and Mokgalo, L (2017) Domestic tourism challenges in Botswana: A stakeholders' perspective. Cogent Social Sciences.

Mbaiwa, J.E. E Toteng E. Moswete, N. and Flores, N. (2007) Problems and prospects for the development of urban tourism in Gaborone and Maun, Botswana Development South Africa. 3, 725-740

Nunkoo, R. and Ramkissoon, H. (2009). Applying the means-end chain theory and the laddering technique to the study of host attitudes to tourism. 337-355.

Olson, J. C., and T. J. Reynolds (2001). The Means-End Approach to Understanding Consumer Decision Making. Understanding Consumer Decision Making: The Means-End Approach to Marketing and Advertising Strategy. T. J. Reynolds and J. C. Olson. London, Lawrence Erlbaurn Associates.

Opuku, R. (2017), Online brand personalities: an exploratory analysis of selected African countries, Place Branding, 2 (2), 11829.

Pike, S. (2009). Destination brand positions of a competitive set of near-home destinations. Tourism Management, 30(6), 857866

Pike, S. (2005). Tourism destination branding complexity. Journal of Product and Brand Management, 14(4), 258-259.

Pearce, P. (2011) Travel motivation, benefits, and constraints to destinations. Destination Marketing and Management: Theories and Applications. Cambridge, MA: CAB International, 39-52.

Progano, R. N, Kumi, K. and Cheer, J. M, (2020) Visitor diversification in pilgrimage destinations: comparing national and international visitors through means-end An International Journal of Tourism Space, Place and Environment 1 (4). 303 - 319.

Quinn, L.P. (2010). A Comparison of Philosophies for Regions: Wiley Online Library

Ritchi, B. G and Crouch, G (1993). A model of destination competitiveness/ sustainability: Brazilian perspective. Rap - Rio de Janeiro 44(5)1049-66.

Reutterer, T. Teller, C. and Schnedlitz, P. (2006). Hedonic and Utilitarian Shopper Types in Evolved and Created Retail Agglomerations. International Review of Retail, Distribution and Consumer Research, 18 (3), 283-309.

Reynolds T.J., Whitlark D.B., (1995). Applying laddering data to communications strategy and advertising practice. Journal of Advertising Research, July/ August.

Rogerson, C. M. and Lisa, Z. (2005). Changing domestic tourism in South Africa. Urban Forum. Springer, 88-111.

San Martín, H. and Rodríguez del Bosque, I. A. (2008). Exploring the cognitive-affective nature of destination image and the role of psychological factors in its formation. Tourism Management, 29(2), 263-277

Scott, N. and Ding, P. (2015) Using means-end chain theory to explore travel motivation: An examination of Chinese outbound tourists. Journal of Vacation Marketing. 21(1) 87-100. 
Scheyvens, R. (2007). Poor cousins no more valuing the development potential of domestic and diaspora tourism. Progress in Development Studies, 7, 307-325.

Sinyenga, G. (2005). Natural based tourism demand in Zambia. Tourism demand survey report. Lusaka. Zambia. Sindiga, I. (1996). Domestic tourism in Kenya. Annals of Tourism Research, 23, 19-31.

Stewart, D. W. (1991). Consumer Self-Selection and Segments of One. The Growing Role of Consumers in Segmentation. Advances in Consumer Research, Association for Consumer Research. 18: 179.

Stylidis, D. Shani, A. and Belhassen, Y. (2017). Testing an integrated destination image model across residents and tourists. Tourism Management, 58, 184-195.

Somnez and Siralcaya (2002) "Determining future travel behaviour from past travel experience and perceptions of risk and safety", Journal of Travel Research. (37), 171-177.

Tasci, A. D. A. and Gartner, W. C. (2007). Destination Image and Its Functional Relationships. Journal of Travel Research, 45(4), 413-425.

Taylor, T.K and Banda-Thole, C. (2013). Tourism Development Potential of the Northern Province of Zambia, American Journal of Tourism Management 2013, 2(1A): 10-25

Wua, T. Lina, Y. Wall, G. and Xie, P. F (2019). A spectrum of indigenous tourism experiences as revealed through means end chain analysis. Journal of Tourism Management 76. 